September 28, igoi.

FOOLHARDY ATTEMPTS AT PABSING TBE WBIRLPOOL BAPIDS $(\because$ NIAGARA.

PIDS $C$. NIAGABA.

On July 9, 1900, Peter Nissen, of Chicago, made a trip through the whirlpool rapids of Niagara in a boat of his own construction. On Nissen's return home he conceived the idea of rebuilding his boat in orde that he might take a series of soundings close to the falls and also in the whirlpool. On this new oraft pol. expended much time and labor, and at this writing it is at Niagara Falls in readiness for another trip, which is scheduled to take place while we are on the press. Before a p p oaching the whirlpool Mr. Nissen will investigate the mysteries of the waters in the gorge between waters in the gorge between the falls and the rapids, and he hopes to be able to obtain data in regard to the river
bottom that will be valuable in connection with this strange river, which has al ways commanded the attention of geologists and scientists. It is Mr. Nissen's ide that in his craft hen's idea that in his craft he can approach very close to the sheet of falling water and there take soundings that will tell to what extent the great downpour of water is affecting the bottom of the river. He expects to go much closer than any human being has yet approached the great Horseshoe, and at the point where it breaks over the shelving precipice, he hopes to sound the bottom.

The length of Mr. Nissen's boat is 21 feet, while it has an outside beam of 4 feet and a height of 6 feet 6 inches. The present boat is claimed to be the smallest full-decked steamer in the world. In shape it somewhat resembles a whaleback. The wood used in the construction of the boat is oak, elm and pine. The deck is of oak and pine. The total weight of the boat is between four and five tons. The wooden keel has an iron weight or tons The wooden keel has an iron weight or addional ke pounds, as compared with pounds of last year's boat. The only part of the old boat that shows in the new boat is the sternpost. Eleven new ribs have been added, and new parts substituted for old parts.

At the port of Chicago the boat is registered as the "Fool-Killer," a pleasure launch, and Nissen by the papers is allowed to carry two people, which includes the crew. Amidships the new boat is a foot higher than the boat of last year, but it is of the same height at the stem and stern. It draws nearly four feet of water. It is painted red at the bottom to the water line, and white above that point, two streaks of natural oak being on each side near the

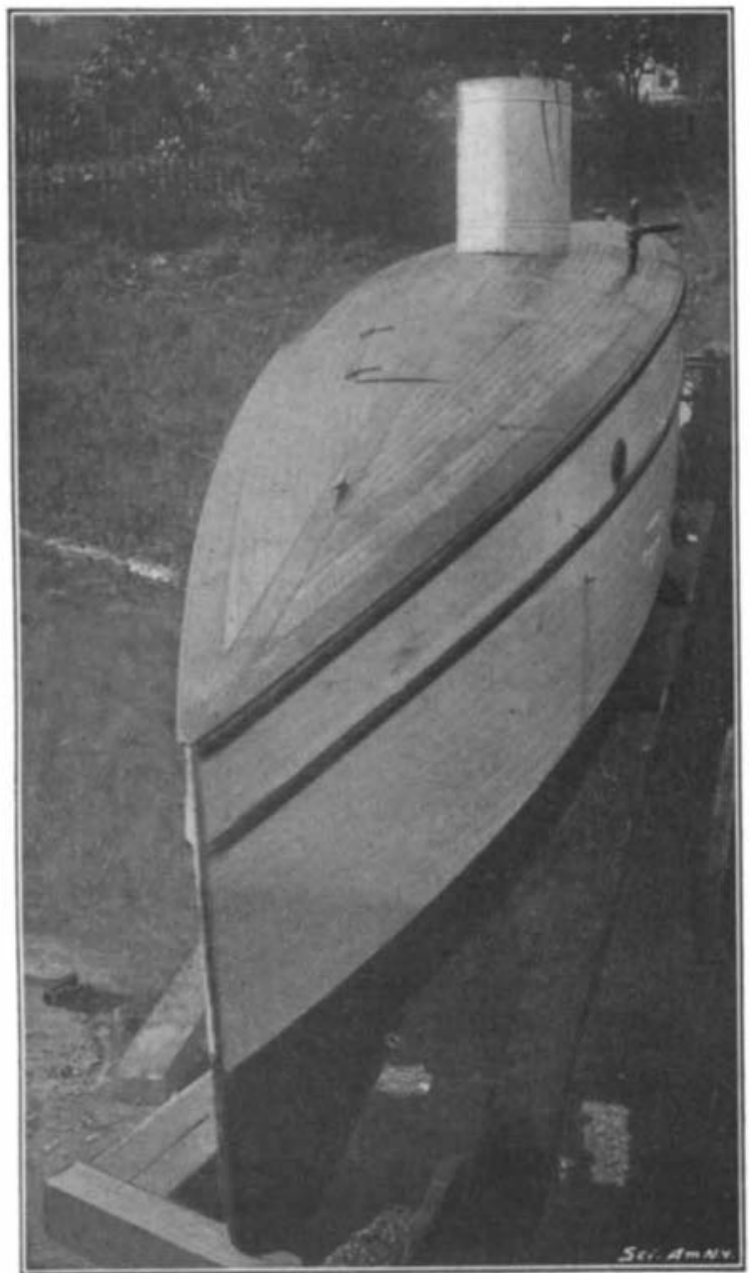

BOW VLEW OF NLSSEN'S " FOOL.RJLLER IL."

\section{צ́rientific Ammerican.}

top and about a foot apart. Examining the boat from the exterior one sees two deadlights, or windows, set about eight feet back from the stem, one on each side of the engine room. The glasses are about 4 inches in diameter and of heavy plate, affording ample light to look about the engine room. They are set about 10 inches below the deck. The 4 inches inside diameter

cork to support the boat in case of springing a leak. It is understood that the craft has been tested and it was found that it is impossible to sink the boat even though it is full of water. In running the boat Nissen occupies bench on the starboard side of the engine. Facilities for making soundings are afforded by a sounding pipe 4 inches inside diameter extending from a point above the water line in the engine room through the bottom of the boat. Over the engine room there is a hatch that can be left open in quiet water, and closed in rough water. Last year in his trip through the whirlpool rapids. and for an hour when he was in the whirlpool, Nissen occupied an open cockpit, but this year it will be possible for him to be wholly covered. MISS WILLARD'S FATAL TRIP IN A BARREL.

So far as known, the first craft to pass through the whirlpool rapids of Niagar with human beings aboard was the small steamer "Maid of the Mist" on June 6, 1861. There were three men on board this boat, the principal one being Joel Robinson, who won renown by the daring feat. From that time un GUALEST FULL-DECRED STEAMER IN THE WORLD.

rudder of the boat is of wrought iron, and has two heavy wrought iron hinges that are bolted through the sternpost. The cross-section of the steel heelplate is $11 /$ inches by 5 inches. It forms an extenpion if the keel. The lower end of the rudder runs sion of the keel. The

The propeller is four-bladed and 28 inches in diameter, quite large enough for a 40 -foot boat. It is a

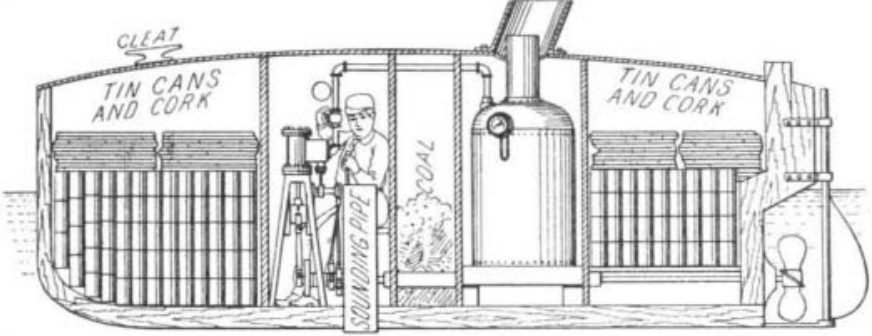

DIAGRAM SHOWING ARRANGEMENT OF THE FOOL-RILLER II"

high-speed wheel with an unusually short pitch. It will be recalled that when Nissen's boat passed out of the whirlpool last year it lost the rudder, propeller and iron keel before it reached Lewiston. Nissen's trip of last year was finished at the whirlpool, the boat being next day sent on to Lewiston. The injury received was from rocks near the Devil's Hole.

The interior of the boat is divided into five spaces, one at either end for corks and cans, an engine room, coal room and a boiler room. Separating these compartments are bulkheads, four in number, but not water tight. The first of these bulkheads is forward of the engine the engine room, and bulkheads fore and aft of the boiler room The bulkheads are made of 3 -inch pine.

The engine installed is a common slide. valve, link motion, made for marine purposes and of about 8 horse power. It is connected to the propeller by a shaft $1 \frac{1}{4}$ inche in diameter. The engine is located forward of the boiler, and this oraft through an iron pipe that runs through a tunnel. The engine room measures 3 feet by 3 feet. Between measures 3 feet by 3 feet. Between the engine room and the boiler room there is a space 15 inches wide by the width of the boat for coal, tools, etc. The boiler installed is of the porcupine tubular type and of 8 horse power. There are two injectors and a hand pump for supplying water to the boiler, while the necessary gages, water column and gage cocks, together with steam siphon, having a capacity of about 500 gallons an hour, for emptying the boat, are in place.

The sections of the boat forward of the engine room and aft of the boile room are filled with tin cans and room; the second in the rear of

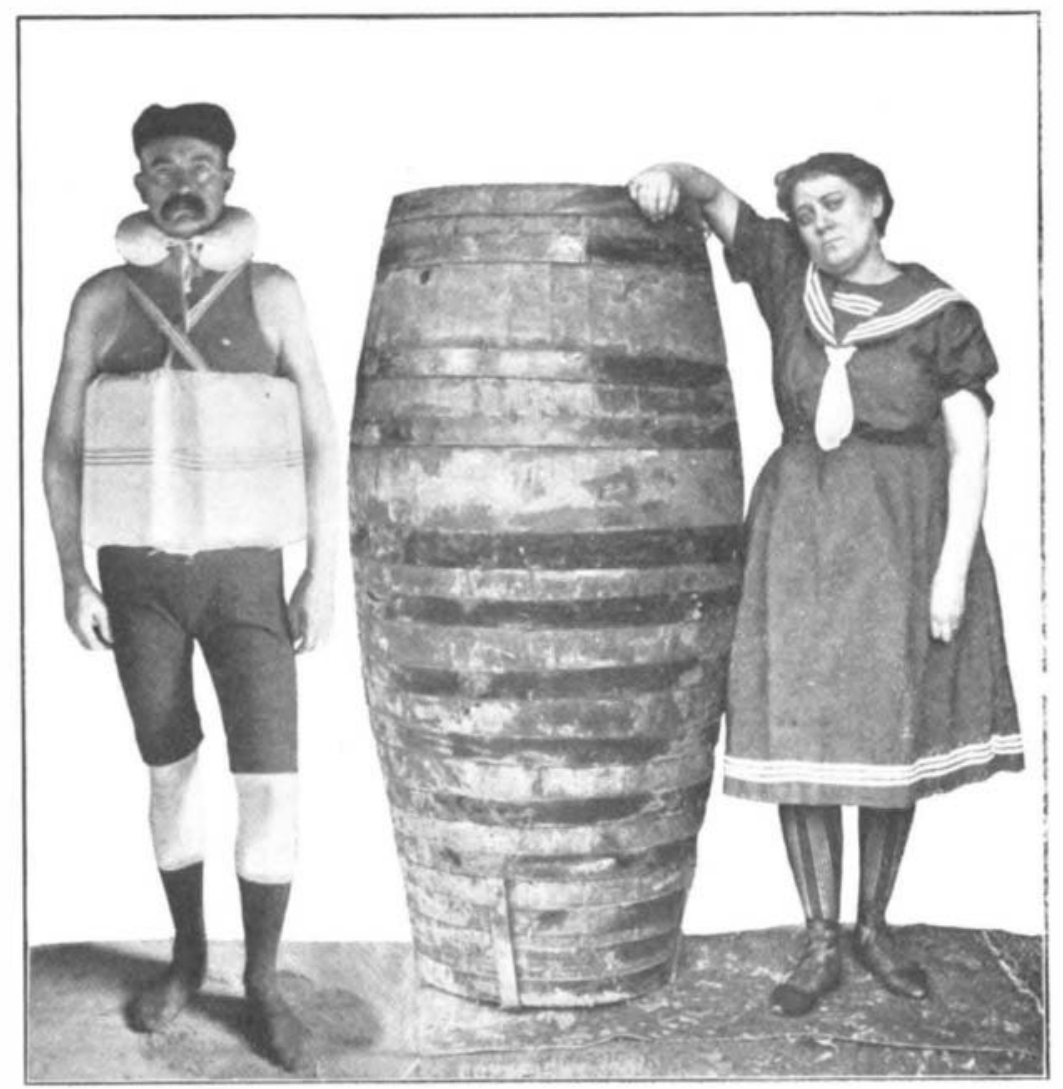

Copyrighted, 1901, by O. E. Dunlap.

C. D. GRAHAH, WHO MADE A NOTABLE SWIMMING RECORD DOWN THE WIAGARA RIVER, AND MISS WILLARD, WHO LOST HER LIFE IN THE til 1883 no person braved the billows of the wonderful gorge. In 1883, however, Capt. Matthew Webb, an neyed to Niagara, bent on swimming through the rapids. He attempted the feat on July 24, 1883, and lost his life.

The death of Webb had a stimulating effect on navigating the rapids presented

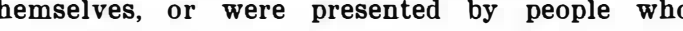
ought fame and dollars. One such was Car nounced that he would build a barrel in which he could navigate the rapids and whirlpool. There was some little laughter at the thought of a human being rushing through the turbulent waters of the Niagara gorge inclosed in a bar rel, but all the jokes cracked did not deter Grabam from carrying out his scheme, and on the afternoon of Sunday, July 11, 1886, Graham surprised everybody by not only gowent down to Lewiston, the full length of he rorge. Since that time he has made four ther rapids trips in his barrel. One of these was made on July 13 last, when he landed at the whirl-

thesuls of Graham's last barrel trip was to arouse the ambition of Miss Maud Willard to make a similar trip, the result being that Graham and Miss Willard agreed to navigate the gorge on Saturday, September 7. The plan was to have Miss 
Willard make the rapids voyage in Graham's barrol while Graham, protected by a llfe preserver, was to swim from the whirlpool to Lewiston, a feat neve successfully performed up to that time.

On the afternoon referred to Miss Willard and th barrel were cast adrift above the lower bridges at 3:58 o'clock. Two minutes later she passed under th bridges, and at 4:04 P. M: the barrel entered the whirlpool. It had been the experience that barrels and boats were captured and withdrawn from the pool within an hour after entering there, but in Miss Willard's case the barrel was not caught until after 9 P. M., and she had been floating in the pool over flve hours. When she entered the barrel she took her pet dog for company's sake. When the barrel was lande the dog was alive, but Miss Willard was dead. She i the first woman to lose her life in navigating the whirlpool rapids of Niagara. The day before Miss Willard's trip, Martha Wagenfluhrer made the trip Whlards trip, Martha Wagenfluhre trip is the only woman who ever went through the whirl pool rapids alone. On November 28, 1886, Sadie Allen made the trip in a barrel of different construction with George Hazlett.

While Miss Willard was still floating in the pool, Carlisle D. Graham, in order to accommodate a moving picture machine present that day, left the pool and swam to Lewiston, making the trip in safety. $\mathrm{He}$ wais attired as shown in the illustration. Between the whirlpool and Lewiston there is considerable rough water, but Graham passed the breakers in safety. Returning to the whirlpool after going to Lewiston, Graham made ineffectual efforts to rescue Niss Willard's barrel, and in doing so was irightfully battered and pounded by driftwood in the pool.

A DESTRUCTIVE BOLT OF LIGHTNING

How erratic and how destructive lightning may often be was brought home to the cottagers who live in the vicinity of Saratoga in a way they will not readily forget. During a recent storm a dwelling was struck with effects that are vividly told by the photographs herewith reproduced. The lightning first struck the chimney, passed down into a bed chamber, wrecked the bed and turned it over, twisted a picture completely around so that it faced the wall, and finally broke through the side of the house, leaving a large gap. Fortunately the bed was unoccupied during the night of the storm

The wall and ceiling of the parlor beneath the bed chamber were also badly damaged. A piano suffered considerably, and a violin, on top of the piano, was hurled across the room and broken. Many panes of glass were shattered. Strange to relate, a clock and hanging lamp almost directly in the path of the bolt were uninjured.

\section{Balloon Ascension.}

In a balloon ascension made on the 31st of July at Berlin, Messrs. Bersen and Sur. ing, two German physicists, reached a height of 31,800 feet. The balloon had a capacity of 272,000 cubic feet, but only received 204,000 feet of pure hydrogen gas prepared by the electrolytic process at the Tempelhof aerostatic park. The hydrogen for filling the balloons is contained in steel tubes having a volume of 350 gallons each, in which the gas is under a pressure of 100 atmospheres. The balloon rose rapidly and at an altitude of 4,600 feet passed a cloudbank of 1,000 feet thickness which did not hide th whole of the earth's surface from view, as they were able to see distinctly the river Spree as far as Niggel, and the Havel as far as Brandenburg. There were no more clouds up to a height of 30,000 feet and at this point they were on a level with a second cloud-bank point they thickness could not be estimated. The aeronaut were protected against the cold by a special apparatus called "thermophore," the details of which have not yet been made public. The voyagers employed inhalations of pure oxygen, which protected them against the effects of the rarefaction of the air up to a certain point. It was only at a height of 27,000 feet that they began to suffer from the rare faction, and this effect increased as they rose. At 31,000 feet the two aeronauts both became unconscious at about the same time, but previously to thi M. Bersen had taken the precaution to open the escape-valve, so that after mounting to 31,800 feet the balloon began to descend. The aeronauts remained unconscious for 30 to 45 minutes, but they became quite restored upon reaching a lower level, and ex perienced no bad effects. It is probable that this un consciousness was caused by the lowering of the reached during the ascension was only $-40 \mathrm{deg}$. C., which is less than was expeeted. The relatively high temperature at these altitudes is a fact which has been observed at different times in the tests made with sounding balloons. These have been sent up as high as 45,000 to 55,000 feet and have nowhere registered below $-70 \mathrm{deg}$. Further study will be necessary in order to elucidate this question.

\section{The Wastage of shipping.}

The tonnage launched in three months in the United Kingdom totaled 398,585 tons, the measurement of 177 vessels, and now an official report records th waste of shipping as 224 vessels of 171,996 , tons, so that the tonnage added to credit is more than double that shown on the debit side. Moreover, while 392,864 tons of the new ships were steam-propelled, only 91,781 tons of the waste was in steamers, and thus the carrying efficiency of the new vessels is nearly four times that of the vessels removed from Lloyd's Regis try, from which the returns are issued. says the Engineer. Obviously the difference means keener com petition. The wastage indicated is much under the baromotric prosaure. The minimum temperature

tho proportion mero: Italy, 216; Norwas, 161; Spaln 35; Sweden, 68; United States, 67; France, 64; Russia, 49; and Germany, 36 .

\section{Attention to Pipes and Traps a Matter of}

The Brooklyn Daily Eagle gives the following useful advice on household sanitation:

The plumber and the plumber's bill are bugbears in nearly every household, but frequently the visit of the mechanic is made necessary through carelessness or ignorance on the part of the members of the household, and many a dollar might be saved were the mistress of the house to look well to the usage of the pipes and traps. A rag, a bit of string, a burn rnatch or a strand or two of hair are not of much account in themselves, but they can create havo where plumbing is concerned, and lay the foundation for a steep bill for repairs to the pipes that would naturally be expected to carry off such little things without any difficulty. But the rag hanging over the bend of the trap may prove instrumental in removing the water seal and thus subject the household to the danger of 'sewer gas invasion and subsequent disease. A string, if it becomes twisted, will accomplish the same result. Burnt matches are harmless enough unless they chance to get jammed into a crevice where they serve as a magnet for other solid particles and the result is a decaying mass that is dangerous as well as offensive. Hair, however, is calculated to produce the great est amount of harm. It acts as a sort of strainer, catching and holding all that passes and is especially partial to bits of soap. In addition hair will lodge in the most inconvenient places and catch upon the least roughness inside the pipe, remaining there until by accretion the space is clogged

Coffee and tea grounds should not be permitted to find their way into a pipe, for if they do not clog it they effect serious injury in a short time through a com

Not the smallest particle of grease should be allowed to go into the pipes, and frying utensils ought to be filled with very hot soda water and allowed to stand for some time before washing. Milky water, unless the pipes are frequently and thoroughly flushed with soda water or lime water, will foul the pipes even if but a small quantity be sent down daily.

Another point to be observed if the housewife would be spared worry is that the scouring grit be left out of the joints when the faucets are scoured. The particles, no matter how fine, quickly injure the screw threads. Care should be taken also in washing sandy vegetables to use a big pan and prevent the sand draining off with the dirty water. Even a spoonful of sand going down a pipe will injure it.

Sinks and closets should be treated to weekly flushing of boiling water with additional flushings of copperas water or chloride of lime solution. Set bowls should re ceive additional attention in the occasional swabbing out of the waste vent, using swab of cotton attached to a coarse crochet hook. Bath tub drain vents may be cleaned in the same way.

Despite constant vigilance pipes will wear out and break, faucets will leak and the plumbing in general require overhauling but much inconvenience and expense may be spared if careful supervision be kept over

THE INTERIOR OF A ROOM WRECKED BY LIGHTNING.

average, for the twelve months' total usually is between 780,000 and 850,000 tons, or at the rate of 210,000 tons per quarter, as compared with the 171,996 tons now reported. We have indicated that the loss is fairly equally divided between steamers and sailing vessels; steel vessels account for one third, iron ships accounting for 61,390 tons, and wooden or composite vessels for 52,187 tons. Since few iron or wooden craft have been built for some years, it will be seen that most of the vessels lost were of some antiquity. Wrecks, as usual, accounted for the greater half of the waste-126 vessels, of 85,078 tons, being thus lost-while 28 vessels, of 24,754 tons, were broken up or condemned. Fires claimed 10 vessels, of 18,807 tons, most of them, curiously enough, being sailin ships; 15 vessels were posted "missing," the tonnage of these averaging nearly 1,000. Nineteen vessels, of 10,661 tons, were abandoned at sea. Collisions sent to the bottom 13 vessels, of 10,199 tons, most of them steamers. Eight vessels, of 7,137 tons, foundered, and five vessels, of 1,815 tons, were otherwise lost. It is gratifying to note that only 47 tons out of every 10,000 tons owned by Britain were lost during the quarter, whereas with other notable maritime powers drain pipes and traps.

The Eiffel Tower of Paris has proved of immense value as a meteorological station. The extreme height of its topmost platform above the surrounding country has enabled some valuable data to be obtained regarding the wind velocity and atmospheric temperature at that altitude. A complete record of observabeen made. The meteorological instruments are situated on the uppermost platform, and are connected electrically with a station below. Hourly records ar by this means obtained. A curious fact has been noticed in connection with these observations. It is impossible to obtain any record of the rainfall at the summit of the tower. The velocity of the wind at that altitude is so great that practically the rain drops travel in a horizontal direction, and thus the rain gages do not receive them. Even in a heavy storm, this peculiarity has been observed. According to the record, the velocity of the wind at the top of the tower is more than three times that at a height of 70 feet above the ground and the normal volo exceeds a speed of 18 miles per hour. tions ever since the opening of the tower, in 1889 , ha 